\title{
치과용 $\mathrm{Ti}-10 \% \mathrm{Zr}-\mathrm{X} \% \mathrm{Cr}(\mathrm{X}=0,1,3)$ 합금의 연삭성
}

\author{
정 종 현, 신 재 우
}

광주보건대학교 치기공과

\section{Grindability of Ti-10\%Zr-X\% $\mathrm{Cr}(\mathrm{X}=0,1,3)$ Alloys for Dental Applications}

\author{
J ong-Hyun J ung, J ae-Woo Shin \\ Dept. of Dental Lab. Technology, Gwangju Health University, Gwangju 506-701, South Korea
}

\section{[Abstract]}

Purpose: The grindability of $\mathrm{Ti}-10 \% \mathrm{Zr}-\mathrm{X} \% \mathrm{Cr}(\mathrm{X}=0,1,3)$ alloys in order to develop $\mathrm{Ti}$ alloys for dental applications with better machinability than unalloyed titanium has been evaluated.

Methods: Experimental $\mathrm{Ti}-10 \% \mathrm{Zr}-\mathrm{X} \% \mathrm{Cr}(\mathrm{X}=0,1,3)$ alloys were made in an argon-arc melting furnace. Slabs of experimental alloys were ground using a $\mathrm{SiC}$ abrasive wheel on an electric handpiece at one of the four rotational speeds of the wheel $(12000,18000,25000$ or $30000 \mathrm{rpm})$ by applying a force(100gf). G rindability was evaluated by measuring the amount of metal volume removed per minute(grinding rate) and the volume ratio of metal removed compared to the whed material lost, which was calculated from the diameter loss (grinding ratio). Experimental datas were compared the results with those of $\mathrm{cp}$ - Ti(commercially pure titanium)

Results: It was observed that the grindability of Ti-10\%Zr-X\% $\mathrm{Cr}(\mathrm{X}=0,1,3)$ alloys increased with an increase in the $\mathrm{Cr}$ concentration. More, they are higher than $\mathrm{cp}-\mathrm{Ti}$, particularly the $\mathrm{Ti}-10 \% \mathrm{Zr}-3 \% \mathrm{Cr}$ alloy exhibited the highest grindability at all rotational speeds except $12000 \mathrm{rpm}$. There was significant difference in the grinding rate and grinding ratio between $\mathrm{Ti}-10 \% \mathrm{Zr}-3 \% \mathrm{Cr}$ alloy and $\mathrm{cp}-\mathrm{Ti}$ at all rotational speeds $(\mathrm{p}<0.05)$.

Conclusion: The Ti-10\% Zr-3\% Cr alloy exhibited better grindability at high rotational speeds, great potential for use as a dental machining alloy.

oKey words : Grindability, Ti-10\%Zr-X\% $\mathrm{Cr}(\mathrm{X}=0,1,3)$ alloys, Grinding rate, Grinding ratio, $\mathrm{cp}-\mathrm{Ti}(\mathrm{commerc}$ ially pure titanium)

*이 논문은 2012년 광주보건대학교 연구비지원에 의해 수행되었습니다.

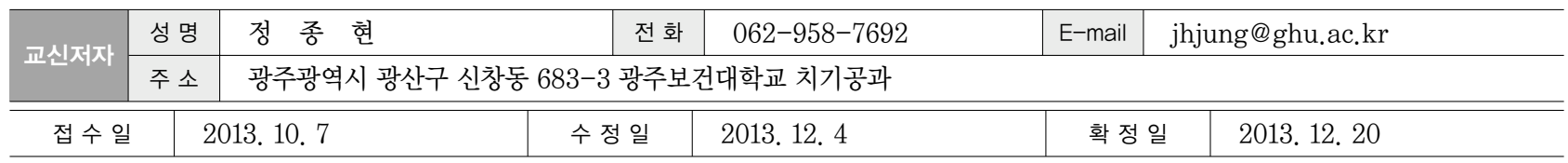




\section{I. 서 론}

$\mathrm{Ti}$ 및 $\mathrm{Ti}$ 합금은 생체적합성이 우수하여 정형외과 임프 란트 뿐만 아니라 치과용 금속재료로 주목 받고 있으나, 정밀주조로 제작된 치과보철물에서 고온산화성 및 고융 점에 의한 주조체 충진율이 낮고 저온 주형재와의 큰 온 도 차이로 기포 발생률이 높게 나타나고 있다(Watanabe at al, 2002).

최근에 시도하고 있는 치과용 $\mathrm{CAD} / \mathrm{CAM}$ 에 의한 보철물 제작시 $\mathrm{Ti}$ 의 연삭가공은 재료의 정밀성 및 균질성 유지 등 의 장점이 있으나 취약한 연삭성으로 연삭시간이 길고 고가 연삭공구의 소모가 크다(Nakajima \& Okabe, 1996). 이는 $\mathrm{Ti}$ 의 고온산화성, 낮은 열전도성 및 높은 연성 때문으로 알 려져 있고(Takeyama \& Murata, 1996), Ti의 연삭성을 개 선하기 위한 대안으로 합금화하는 연구들이 진행되고 있지 만 그리 많지는 않는 편이다(Kikuchi et al, 2003).

생체용으로 널리 사용하고 있는 $\mathrm{Ti}-6 \% \mathrm{Al}-4 \% \mathrm{~V}$ 합금은 $\mathrm{cp}-\mathrm{Ti}$ 보다 물리적 기계적 성질이 우수하나 장기간 사용 시 Al과 V이온의 용출로 건강에 해로울 수 있다. 그러나 대체용 Ti합금 개발을 위한 원소로서 $\mathrm{Zr}$ 는 생체적합성이 우수하고(Okazaki et al, 1996) Ti와 같은 주기율표의 IV $\mathrm{B}$ 족에 속하여 화학적 기계적 성질이 비슷하며 전율고용 에 의한 고용강화현상이 일어난다. 또한 $\mathrm{Cr}$ 은 내식성을 증가 시키고 $\beta$ 공석형 원소로서 액상선 온도를 저하 시키 며 기계적 성질을 개선시킨다(Ho et al, 2009).
따라서 본 연구에서는 $\mathrm{Ti}-10 \% \mathrm{Zr}-\mathrm{X} \% \mathrm{Cr}(\mathrm{X}=0,1.3)$ 합금 을 제조하여 연삭성을 평가하였고, $\mathrm{cp}-\mathrm{Ti}$ 의 연삭성과도 비교분석하였다.

\section{II. 연구 방법}

\section{1. 시료 제조}

$\mathrm{Ti}-\mathrm{Zr}$ 합금은 평형상태도(Murray, 1987)에 의하면 전 율고용형이고 고온의 $\beta$ 상(bcc)에서 저온의 $\alpha$ 상(hcp)으로 동소변태하며, $882^{\circ} \mathrm{C}(\mathrm{Ti})$ 부터 $605^{\circ} \mathrm{C}(67 \mathrm{wt} . \% \mathrm{Zr})$ 까지 $\mathrm{Zr}$ 의 첨가량에 따라 변태온도는 변한다. 본 시료의 기본조 성인 $\mathrm{Ti}-10 \% \mathrm{Zr}$ 합금은 냉각 중 모두 $\beta \rightarrow \alpha$ 상 천이가 일어 나고 실온에서는 균일한 $\alpha$ 상이다.

$\mathrm{Ti}-10 \% \mathrm{Zr}-\mathrm{X} \% \mathrm{Cr}(\mathrm{X}=0,1,3)$ 합금을 설계하고 시료중량 이 $20 \mathrm{~g}$ 되도록 $99 \% \mathrm{Ti}, 98 \% \mathrm{Zr}$ 및 $98 \% \mathrm{Cr}$ 을 계량하였다. 아르곤-아크용해로(VAM-B, Hyungjae vacuum, Korea)에 시료를 장입하고 10-3 torr까지 진공을 유지한 후 아르곤 가스를 주입하고 아크 용해하였다. diamond wheel cutter로 copper hearth에서 냉각된 시료 인곳트 와 비교군 $\mathrm{cp}-\mathrm{Ti}$ 를 두께 $2 \mathrm{~mm}$ 로 절단하여 시험조건에 따 라 3개씩 제작하였다.

시험시료의 EDS(Energy Dispersive X-ray Spectrometer)분석결과는 〈Table 1〉과 같고, 비교군인 $\mathrm{cp}-\mathrm{Ti}$ 의 화학성분은 〈Table 2 〉와 같다.

Table 1. EDS-determined alloy compositions for the study (wt\%)

\begin{tabular}{|c|c|c|c|c|}
\hline \multirow{4}{*}{$\begin{array}{c}\text { Experimental } \\
\text { specimen alloys }\end{array}$} & Alloy code & $\mathrm{Zr}$ & $\mathrm{Cr}$ & $\mathrm{Ti}$ \\
\hline & $\mathrm{Ti}-10 \% \mathrm{Zr}$ & $9.23 \pm 0.34$ & & Bal. \\
\hline & $\mathrm{Ti}-10 \% \mathrm{Zr}-1 \% \mathrm{Cr}$ & $9.31 \pm 0.42$ & $0.8 \pm 0.50$ & Bal. \\
\hline & $\mathrm{Ti}-10 \% \mathrm{Zr}-3 \% \mathrm{Cr}$ & $9.37 \pm 0.33$ & $2.4 \pm 0.47$ & Bal. \\
\hline
\end{tabular}

Table 2. Chemical compositions of control (wt\%)

\begin{tabular}{cccccccccc}
\hline \multirow{3}{*}{ Control } & & $\mathrm{Al}$ & $\mathrm{V}$ & $\mathrm{Fe}$ & $\mathrm{C}$ & $\mathrm{H}$ & $\mathrm{O}$ & $\mathrm{N}$ & $\mathrm{Ti}$ \\
\cline { 2 - 9 } & $\mathrm{cp}-\mathrm{Ti}$ (Grade 2) & & & 0.30 & 0.10 & 0.015 & 0.25 & 0.03 & Bal. \\
\hline
\end{tabular}




\section{2. 연삭 시험}

이전의 연삭성 시험연구(Jung \& Noh, 2011)에서와 같은 방법으로 시행하였다. 치과용 헨드피스에 끼운 두께 $1.5 \mathrm{~mm}$, 직경 13.0mm의 카보런덤 휠(SiC DURA-Green Stones, Shofu, Japan) 연삭기구를 시편의 연삭면과 $90^{\circ}$ 의 위치관 계로 두고, 하중 $100 \mathrm{~g}$, 연삭기구 회전속도 12000,18000 , 25000 및 $30000 \mathrm{rpm}$ 의 각각 시험조건으로 1 분간 연삭하였 고 시편의 연삭 전후의 무게 감소량을 측정하였다. 각 시편 의 무게 감소량과 밀도로 부터 삭제된 부피량 즉 연삭량 (grinding rate)을 구하였고, 연삭량 대비 카보런덤 휠의 연 삭 전후의 지름 감소량으로 연삭효율(grinding ratio)을 구 하였다. 연삭시험은 각 시험조건별로 3 회 시행하였으며 시 료 간 및 회전속도 간의 통계적 유의성을 알아보기 위해 일 원배치법 분산분석(one-way ANOVA)과 사후검정으로 Scheffe's test $(\alpha=0.05)$ 를 하였다.

\section{3. 시료의 DS 분석 및 연삭 chip, 연삭면의 전자현미 경 (SEM) 관찰}

각 시료를 $\mathrm{EDS}(\mathrm{EX}-250$, Horiba, Japan)로 성분 분석하 였고, 하중 $100 \mathrm{~g}$, 회전속도 $18000 \mathrm{rpm}$ 에서 1 분간 연삭한 후에 연삭 chip 및 연삭면을 전자현미경(SEM, s-4800, Hitachi, Japan)으로 관찰하였다.

\section{III. 결 과}

\section{1. 연삭성}

〈Fig. 1〉은 $\mathrm{Ti}-10 \% \mathrm{Zr}-\mathrm{X} \% \mathrm{Cr}(\mathrm{X}=0,1,3)$ 합금 및 $\mathrm{cp}-\mathrm{Ti}$ 시편에 하중 $100 \mathrm{~g}$ 을 적용하여 1 분간 연삭하고 측정한 무 게감소량에 대해 밀도로부터 연삭량을 구하여 시료 및 연 삭기구의 회전속도(12000, 18000, 25000, 30000rpm)별 로 나타낸 것이다. 12000,18000 및 $25000 \mathrm{rpm}$ 에서의 $\mathrm{Ti}-10 \% \mathrm{Zr}-\mathrm{X} \% \mathrm{Cr}(\mathrm{X}=0,1,3)$ 합금의 연삭량은 회전속도가 증가함에 따라 점점 높아지는 경향을 보였고, 이러한 경 향은 $\mathrm{cp}-\mathrm{Ti}$ 에서도 나타났다. 그러나 초고속인 $30000 \mathrm{rpm}$ 에서는 $\mathrm{Ti}-10 \% \mathrm{Zr}-1 \% \mathrm{Cr}$ 합금을 제외한 모든 시료에서 오히려 감소하는 경향을 보였다. $\mathrm{Ti}-10 \% \mathrm{Zr}-$ $1 \% \mathrm{Cr}$ 합금의 경우 $30000 \mathrm{rpm}$ 에서 $25000 \mathrm{rpm}$ 보다 약간
연삭량이 높게 나타났으나 유의한 차이를 보이지 않았고, $\mathrm{Ti}-10 \% \mathrm{Zr}-3 \% \mathrm{Cr}$ 합금의 연삭량이 다른 시료에 비해 $12000 \mathrm{rpm}$ 을 제외한 이 이상의 고속회전속도 모두에서 가장 높게 나타났다.

〈Fig. 2〉는 연삭기구의 회전속도별로 시료의 연삭량 간 통계적 유의성을 검증하여 나타낸 것이다. 회전속도 $12000 \mathrm{rpm}$ 에서의 연삭량은 $\mathrm{Ti}-10 \% \mathrm{Zr}-\mathrm{X} \% \mathrm{Cr}(\mathrm{X}=0,1,3)$ 합금의 경우에 $\mathrm{Ti}-10 \% \mathrm{Zr}, \mathrm{Ti}-10 \% \mathrm{Zr}-1 \% \mathrm{Cr}$ 합금 순으로 증가하다가 $\mathrm{Ti}-10 \% \mathrm{Zr}-3 \% \mathrm{Cr}$ 합금에서는 약간 감소하였 다. $\mathrm{Ti}-10 \% \mathrm{Zr}$ 와 $\mathrm{Cr}$ 원소가 첨가된 $\mathrm{Ti}-10 \% \mathrm{Zr}-1 \% \mathrm{Cr}$ 및 $\mathrm{Ti}-10 \% \mathrm{Zr}-3 \% \mathrm{Cr}$ 합금 간에는 유의한 차이가 나타났다 $(\mathrm{p}\langle 0.05)$. 가장 높게 나타난 $\mathrm{Ti}-10 \% \mathrm{Zr}-1 \% \mathrm{Cr}$ 합금의 연 삭량은 가장 낮은 $\mathrm{cp}-\mathrm{Ti}$ 및 $\mathrm{Ti}-10 \% \mathrm{Zr}$ 합금과는 유의한 차이를 보였지만(p<0.05), Ti-10\%Zr-3\% Cr합금과는 유 의한 차이가 나타나지 않았다. 연삭기구 $18000 \mathrm{rpm}$ 에서 의 연삭량은 $12000 \mathrm{rpm}$ 에서와 달리 $\mathrm{Cr}$ 첨가량 증가에 따 라 $\mathrm{Ti}-10 \% \mathrm{Zr}$ 합금, $\mathrm{Ti}-10 \% \mathrm{Zr}-1 \% \mathrm{Cr}, \mathrm{Ti}-10 \% \mathrm{Zr}-3 \% \mathrm{Cr}$ 합금 순으로 높게 나타났고, 모든 시료 간에 유의한 차이 를 보였다(p<0.05). 고속인 25000rpm 및 30000rpm에 서 시료별 연삭량은 $18000 \mathrm{rpm}$ 에서와 순위 경향은 같았 고 $\mathrm{Ti}-10 \% \mathrm{Zr}-1 \% \mathrm{Cr}$ 및 $\mathrm{Ti}-10 \% \mathrm{Zr}-3 \% \mathrm{Cr}$ 합금의 연삭량 은 높게 나타났으며 서로 유의한 차이를 보이지 않았으나 $\mathrm{Cr}$ 이 첨가되지 않은 $\mathrm{Ti}-10 \% \mathrm{Zr}$ 합금 및 $\mathrm{cp}-\mathrm{Ti}$ 와는 유의 한 차이를 보였다( $\mathrm{p}<0.05)$.

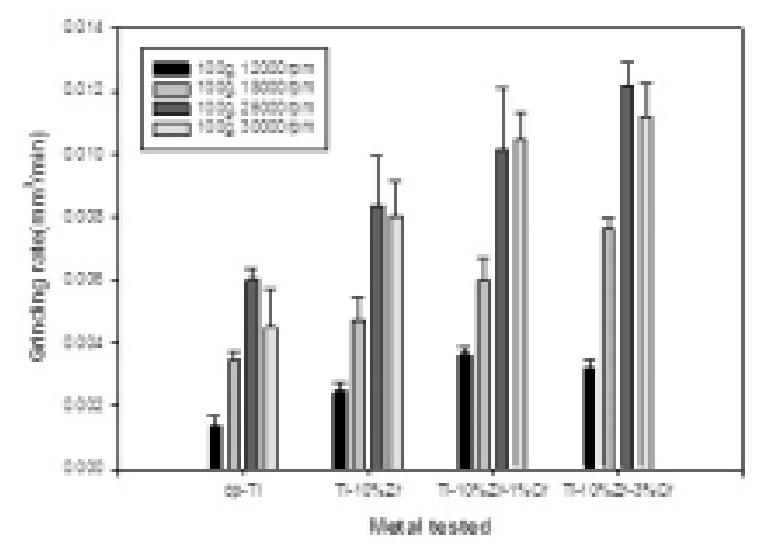

Fig. 1. Grinding rates of $\mathrm{Ti}-10 \% \mathrm{Zr}-\mathrm{X} \% \mathrm{Cr}(\mathrm{X}=0,1,3)$ alloys and $\mathrm{cp}-\mathrm{Ti}$ at four different grinding speeds 


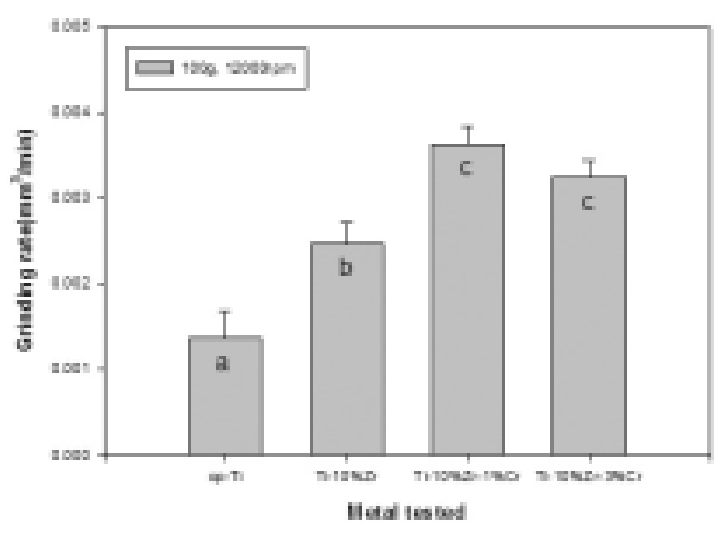

(a) at $12000 \mathrm{rpm}$

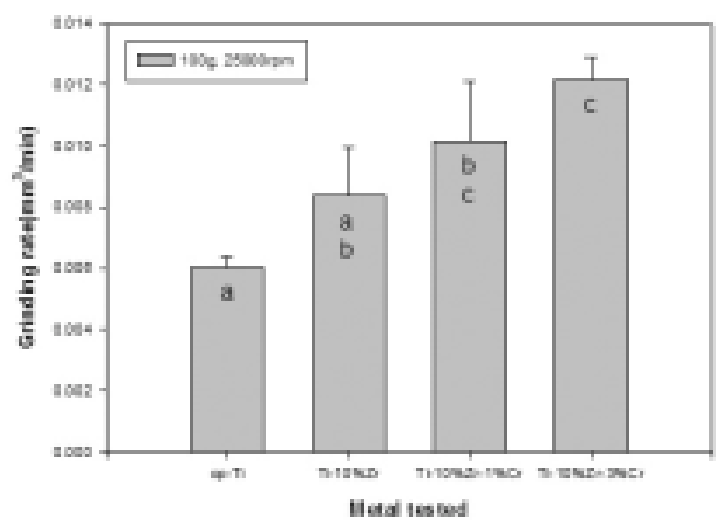

(c) at $25000 \mathrm{rpm}$

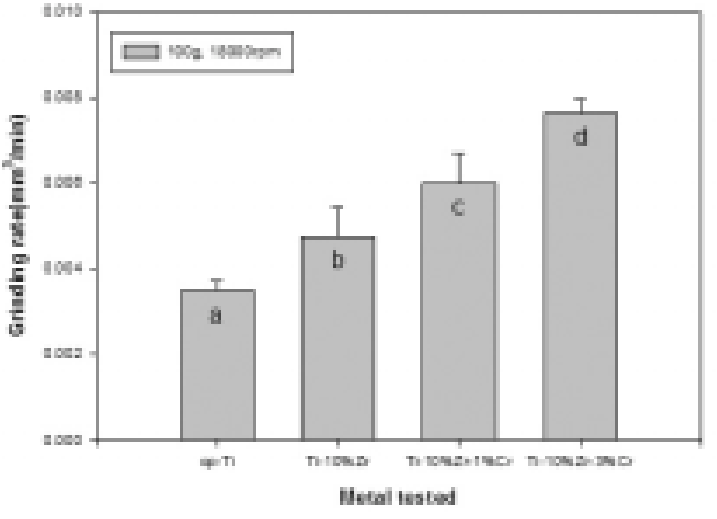

(b) at 18000rpm

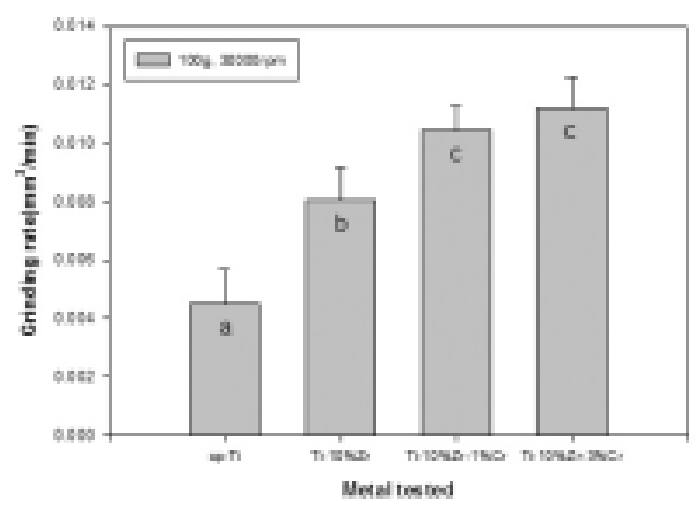

(d) at 30000rpm

Fig. 2. Grinding rates of $\mathrm{Ti}-10 \% \mathrm{Zr}-\mathrm{X} \% \mathrm{Cr}(\mathrm{X}=0,1,3)$ alloys and $\mathrm{cp}-\mathrm{Ti}$ at grinding speeds individually( $(\mathrm{a} \sim \mathrm{d})$, which were evaluated by volume of metal removed per minute. Different letters mean significant difference at $p<0.05$ level

〈Fig. 3〉은 $\mathrm{Ti}-10 \% \mathrm{Zr}-\mathrm{X} \% \mathrm{Cr}(\mathrm{X}=0,1,3)$ 및 $\mathrm{cp}-\mathrm{Ti}$ 에 하 중 $100 \mathrm{~g}$ 을 적용하고 연삭기구의 회전속도별( 12000,18000 , $25000,30000 \mathrm{rpm}$ )로 1분간 연삭한 후에 연삭량 대비 $\mathrm{SiC}$ 휠의 지름 감소량으로 연삭효율(grinding ratio)을 구 하여 나타낸 것이다.

$\mathrm{Ti}-10 \% \mathrm{Zr}-\mathrm{X} \% \mathrm{Cr}(\mathrm{X}=0,1,3)$ 합금의 연삭효율은 회전속 도가 증가함에 따라 높게 나타났으며, $\mathrm{Ti}-10 \% \mathrm{Zr}-1 \% \mathrm{Cr}$ 합금의 연삭효율이 다른 시료에 비해 모든 회전속도에서 가장 높게 나타났고, $\mathrm{cp}-\mathrm{Ti}$ 에 비해 모든 회전속도에서 유 의한 차이를 보였다( $\mathrm{p}<0.05)$.

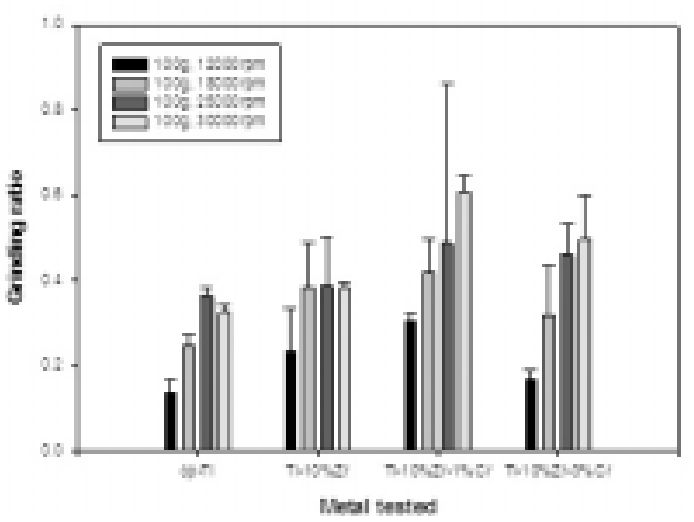

Fig. 3. Grinding ratio of $\mathrm{Ti}-10 \% \mathrm{Zr}-\mathrm{X} \% \mathrm{Cr}(\mathrm{X}=0,1,3)$ alloys and $\mathrm{cp}-\mathrm{Ti}$

The volume ratio of metal removed compared to the wheel material lost(namely grinding ratio), which was calculated from the wheel diameter loss 


\section{2. 연삭 chip 및 연삭면의 전자현미경(SEM) 간찰}

〈Fig. 4〉는 $\mathrm{Ti}-10 \% \mathrm{Zr}-\mathrm{X} \% \mathrm{Cr}(\mathrm{X}=0,1,3)$ 합금 및 $\mathrm{cp}-\mathrm{Ti}$ 에 하중 $100 \mathrm{~g}$ 을 적용하고 회전속도 $18000 \mathrm{rpm}$ 에서 1 분 간 연삭한 후 채취한 금속 chip의 SEM관찰사진이다. $\mathrm{Ti}-10 \% \mathrm{Zr}$ 합금의 chip 입자는 $\mathrm{cp}-\mathrm{Ti}$ 의 chip과 비슷하게 크고 불규칙하며 거친 형태이나, $\mathrm{Ti}-10 \% \mathrm{Zr}-1 \% \mathrm{Cr}$ 및 $\mathrm{Ti}-10 \% \mathrm{Zr}-3 \% \mathrm{Cr}$ 합금의 chip은 상대적으로 작고 균일한 알갱이 형태로 나타났다.

$\langle$ Fig. 5〉는 $\mathrm{Ti}-10 \% \mathrm{Zr}-\mathrm{X} \% \mathrm{Cr}(\mathrm{X}=0,1,3)$ 합금 및 $\mathrm{cp}-\mathrm{Ti}$
에 하중 $100 \mathrm{~g}$ 을 적용하고 회전속도 $18000 \mathrm{rpm}$ 에서 1 분 간 연삭한 후의 연삭면의 SEM관찰사진이다. 모든 시험 조건의 시료에서 연삭면이 뚜렷하게 관찰되었고 회전속 도가 증가함에 따라 다소 차이는 있었으나 마찰열에 의한 탄화흔적인 변색이 짙게 나타났다. 연삭면의 특징으로는 $\mathrm{Ti}-10 \% \mathrm{Zr}, \mathrm{Ti}-10 \% \mathrm{Zr}-1 \% \mathrm{Cr}$ 및 $\mathrm{Ti}-10 \% \mathrm{Zr}-3 \% \mathrm{Cr}$ 합금 은 선명하게 연삭흔이 나타나 비교군인 $\mathrm{cp}-\mathrm{Ti}$ 연삭면에 서 엉겨 붙어있는 것과는 뚜렷한 차이를 보였다.
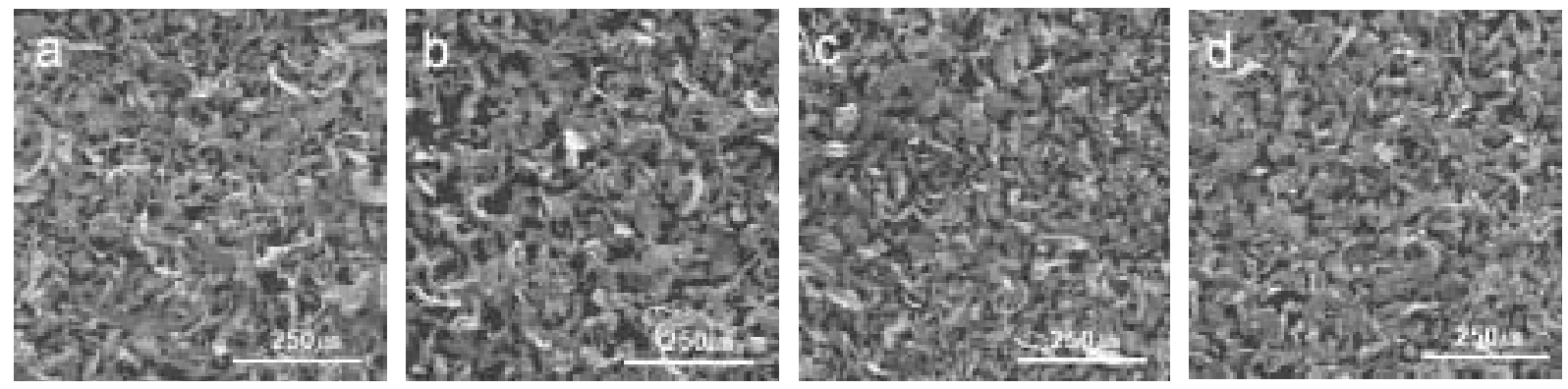

Fig. 4. Scanning electron micrographs of the metal chips resulting from grinding of the specimen alloys at the rotational speeds of 18000 rpm by applying a force of $100 \mathrm{~g}$ : (a) $\mathrm{cp}-\mathrm{Ti}$; (b) $\mathrm{Ti}-10 \% \mathrm{Zr}$ alloy; (c) $\mathrm{Ti}-10 \% \mathrm{Zr}-1 \% \mathrm{Cr}$ alloy; (d) $\mathrm{Ti}-10 \% \mathrm{Zr}-3 \% \mathrm{Cr}$ alloy
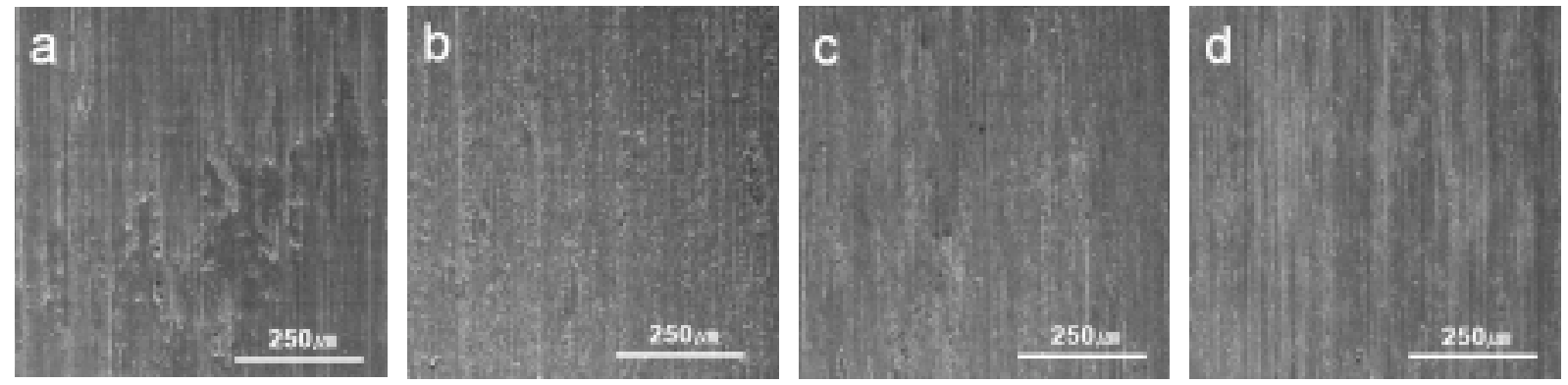

Fig. 5. Scanning electron micrographs of the ground surfaces of the specimen alloys at the rotational speeds of 18000rpm by applying a force of 100g: (a) cp-Ti; (b) Ti-10\%Zr alloy; (c) Ti-10\%Zr-1\%Cr alloy; (d) $\mathrm{Ti}-10 \% \mathrm{Zr}-3 \% \mathrm{Cr}$ alloy

\section{IV. 고 찰}

\section{1. 연삭성}

치과분야에서는 산업현장에서와 달리 $\mathrm{CAD} / \mathrm{CAM}$ 시스 템에서 적용되는 연삭공정에서 공정이나 공구수명을 평 가할 때 일반적으로 단순한 설비로 응용하여 측정하고 있 다(Ho et al, 2008). 본 연구에서는 Kicuchi 등(2003)의
시험방법을 응용하여 하중 및 연삭속도가 일정하게 제어 될 수 있도록 고안된 시험기기를 이용하였다.

연삭성(grindability)평가는 Ho 등(2009)이 시행한 방 법과 같이 연삭기구에 의한 시료의 1 분간 부피삭제량 즉 연삭량(grinding rate)과 연삭기구의 소모량(직경감소) 대비 부피삭제량 즉 연삭효율(grinding ratio)로 하였다. 연삭량은 연삭의 수월정도를 나타내고 연삭효율은 연삭 
기구의 수명을 나타낸다.

〈Fig. 1〉에서 보면 $\mathrm{Ti}-10 \% \mathrm{Zr}-\mathrm{X} \% \mathrm{Cr}(\mathrm{X}=0,1,3)$ 합금의 연삭량(grinding rate)은 $25000 \mathrm{rpm}$ 이하의 회전속도에 서는 연삭기구 회전속도가 증가함에 따라 점점 높게 나타 났으나 초고속 회전속도인 $30000 \mathrm{rpm}$ 에서는 $\mathrm{Ti}-$ $10 \% \mathrm{Zr}-1 \% \mathrm{Cr}$ 합금을 제외한 모든 합금에서 약간 감소하 는 경향을 보였다. 연삭량이 회전속도에 비례해서 증가하 는 것은 회전속도가 시간당 시료면에서 행해지는 연삭기 구의 이동거리의 함수로 나타나기 때문으로 생각되지만, 연삭기구의 고속회전속도에서 연삭량이 오히려 감소하는 경향은 HO 등(2008)이 보고한 Ti-Zr계합금의 연삭성 연 구결과 및 Kikuchi 등(2003)이 보고한 $\mathrm{Ti}-\mathrm{Cu}$ 계 합금의 연삭성 연구결과와 같이 초고속 회전속도에서 발생하는 마찰열에 의한 연삭기구의 열화현상 때문일 가능성 높고, 이에 대해서는 좀 더 연구가 필요하다고 생각된다.

$\mathrm{Ti}-10 \% \mathrm{Zr}-\mathrm{X} \% \mathrm{Cr}(\mathrm{X}=0,1,3)$ 에서 $\mathrm{Cr}$ 원소 첨가량이 더 많을 때 연삭량이 높게 나타난 것은 〈Fig. 6〉과 같이 경도 의 증가 때문으로 생각된다. Kikuchi 등(2003)은 소재의 경도 및 강도가 증가하면 연삭성이 높아진다고 보고한 바 있고, $\beta$ 상 안정화 합금원소인 $\mathrm{Cr}$ 이 $\mathrm{Ti}$ 에 첨가되면 공석반 응하여 bcc결정구조의 $\beta$-공석조직을 이루게 되고 결정입 계와 결정입내에 $\mathrm{TiCr}$ 석출물을 형성하여 기지가 강화되 고 경도가 증가하게 된다(Ho et al, 2009).

또한 본 시료합금인 $\mathrm{Ti}-10 \% \mathrm{Zr}-\mathrm{X} \% \mathrm{Cr}(\mathrm{X}=0,1,3)$ 합금이 비교군인 $\mathrm{cp}-\mathrm{Ti}$ 에 비해서 연삭량이 높게 나타난 것도 경 도의 증가 때문으로 생각된다. $\mathrm{Zr}$ 이 Ti에 첨가되면 전율 고용에 의한 고용강화현상이 일어나게 되는데 합금원소 가 고용되면 용질원자 주위의 결정격자에 탄성적 스트레 인이 발생하여 전위의 운동이 방해되어 금속이 강화 하게 되고 이때 용질원자에 의한 강화량은 용질원자농도의 평 방근에 비례하게 된다(Jung, 2000). 이외에 연삭량 증가 요인으로 탄성계수(Ho et al, 2008)와 관련된 연구결과 도 보고된 바 있다.

〈Fig. 3〉에서 보면 Ti-10\%Zr-1\%Cr합금에서 연삭효율 (grinding ratio)이 가장 높게 나타났다. 연삭효율에 따라 연삭기구의 수명이 평가될 수 있는데 연삭효율이 낮으면 연삭량이 같을 때 연삭기구의 마모량이 많은 것을 의미하 므로 경제성을 고려한 효율적인 연삭속도를 유지하는 것

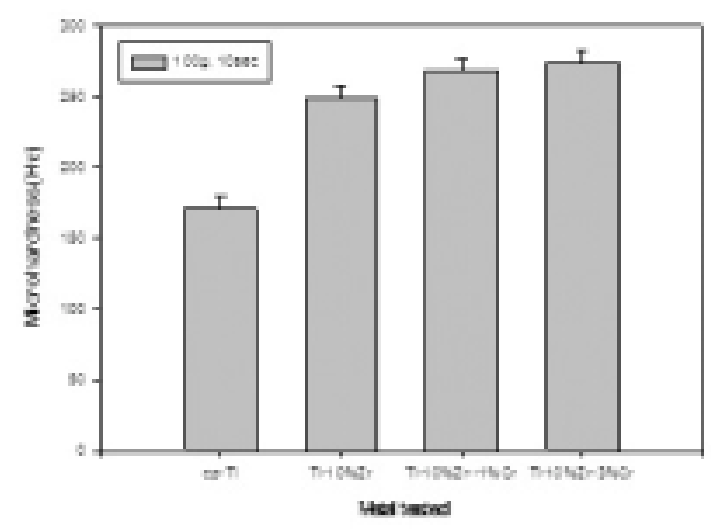

Fig. 6. Microhardness of $\mathrm{cp} \mathrm{Ti}$ and $\mathrm{Ti}-10 \% \mathrm{Zr}-\mathrm{X} \% \mathrm{Cr}$ $(X=0,1,3)$ alloys

이 중요하다(Kikuchi et al, 2006). Ti-10\%Zr$\mathrm{X} \% \mathrm{Cr}(\mathrm{X}=0,1,3)$ 의 연삭효율이 비교군인 $\mathrm{cp}-\mathrm{Ti}$ 에 비해 모 든 속도별에서 높게 나타났다.

연삭효율의 편차가 대체적으로 넓은 것은 시료의 연삭 량과 연삭기구의 소모량이 매우 적어서 측량 오차 때문으 로 생각된다.

\section{2. 연삭 chip 및 연삭면의 전자현미경(SEM) 간찰}

회전속도 $18000 \mathrm{rpm}$ 에서 채취한 chip을 SEM관찰했을 때 $\mathrm{cp}-\mathrm{Ti}$ 와 $\mathrm{Ti}-10 \% \mathrm{Zr}, \mathrm{Ti}-10 \% \mathrm{Zr}-1 \% \mathrm{Cr}, \mathrm{Ti}-10 \% \mathrm{Zr}-$ $3 \% \mathrm{Cr}$ 합금 사이에는 크기에 있어서 차이가 있었다. $\mathrm{Ti}-$ $10 \% \mathrm{Zr}, \mathrm{Ti}-10 \% \mathrm{Zr}-1 \% \mathrm{Cr}$ 및 $\mathrm{Ti}-10 \% \mathrm{Zr}-3 \% \mathrm{Cr}$ 합금에서 비교군인 $\mathrm{cp}-\mathrm{Ti}$ 에 비해 연삭성이 높게 나타난 것은 정량 적으로 측정하지는 않았지만 chip의 형태가 균일하고 크 기가 작을 때 연삭성이 높기 때문으로 생각된다. 반면에 $\mathrm{cp}-\mathrm{Ti}$ 는 거칠고 다양한 형태와 크기가 큰 입자를 보였는 데, 저속일 때 이런 현상이 더 뚜렷하게 나타났다고 보고 된 바 있다(Ho et al, 2008). Ti-10\%Zr과 Ti-10\% Zr$1 \% \mathrm{Cr}, \mathrm{Ti}-10 \% \mathrm{Zr}-3 \% \mathrm{Cr}$ 합금 사이에는 큰 차이가 나타나 지 않았다.

연삭한 후에 연삭면을 육안이나 SEM관찰했을 때 연삭 흔은 모든 시험조건에서 뚜렷하였고 약간의 변색이 나타 났다. 이와 같은 변색은 Ti나 Ti합금이 고온산화성 금속 이므로 고속연삭시 발생한 마모열에 의한 산화현상 때문 으로 생각되고, 고속연삭시험에서 불꽃발생과 더불어 나 타났다. 특히 고속인 30000rpm에서 강하게 일어났는데, 연삭 속도가 증가하면 연삭시 발생한 열도 더 높게 발생 
하게 되고(Ashirura \&Motonishi, 1992), 고속으로 연삭 될 때 가연성이 높은 미세한 chip을 더 많이 발생되기 때 문이다(Chandler, 1989; Dahn, 1989). Zr의 첨가로 융 점이 낮아져서 연삭시 마이크로 융해가 일어나서 (Kikuchi et al, 2003) 보철물의 변색 부식 및 균열의 원 인이 될 수도 있다.

$\mathrm{cp}-\mathrm{Ti}$ 의 표면에는 금속조직이 엉겨 붙어 있어 실험군 인 $\mathrm{Ti}-10 \% \mathrm{Zr}, \mathrm{Ti}-10 \% \mathrm{Zr}-1 \% \mathrm{Cr}$ 및 $\mathrm{Ti}-10 \% \mathrm{Zr}-3 \% \mathrm{Cr}$ 합 금과는 뚜렷한 차이가 나타났다. 이는 Ho 등(2008)이 보 고한 $\mathrm{Ti}-\mathrm{Zr}$ 합금의 연삭성 평가에서 $\mathrm{cp}-\mathrm{Ti}$ 및 $\mathrm{Zr}$ 함량이 $20 \%$ 미만의 합금에서 나타난 현상과 유사하였다.

\section{V. 결 론}

치과용 $\mathrm{Ti}-10 \% \mathrm{Zr}-\mathrm{X} \% \mathrm{Cr}(\mathrm{X}=0,1,3)$ 합금의 연삭성을 연 삭기구의 회전속도별(12000, 18000, 25000 및 $30000 \mathrm{rpm})$ 로 조사하였으며, 비교군인 $\mathrm{cp}-\mathrm{Ti}$ 와도 비교 평가 하였다. $\mathrm{Ti}-10 \% \mathrm{Zr}, \mathrm{Ti}-10 \% \mathrm{Zr}-1 \% \mathrm{Cr}, \mathrm{Ti}-10 \% \mathrm{Zr}-$ $3 \% \mathrm{Cr}$ 합금 등의 연삭량 및 연삭효율은 회전속도별 모두에 서 $\mathrm{cp}-\mathrm{Ti}$ 보다 더 높게 나타났다. 특히 연삭량은 $\mathrm{Ti}-$ $10 \% \mathrm{Zr}-3 \% \mathrm{Cr}$ 합금이 가장 높았고, 연삭효율은 $\mathrm{Ti}-$ $10 \% \mathrm{Zr}-1 \% \mathrm{Cr}$ 합금이 가장 높았으며, $\mathrm{cp}-\mathrm{Ti}$ 과는 유의한 차이를 보였다(p<0.05). 이는 $\mathrm{Zr}$ 원소의 첨가에 의한 전율 고용강화현상 및 $\beta$ 안정화 합금원소인 $\mathrm{Cr}$ 첨가에 의한 강 도 및 경도증가 때문으로 생각되고, 추후 더 깊이 있는 연 구가 요구되지만 $\mathrm{Ti}-10 \% \mathrm{Zr}-3 \% \mathrm{Cr}$ 합금은 치과연삭가공 용으로서 가능성이 높다.

\section{REFERENCES}

Ashirura Y, Motonishi S. Machining, Fabrication technique of titanium, Japan Titanium Society, Tokyo, 19-50, 1992.

Chandler HE. Machining of reactive metas. Metal handbook 9th ed.Vol.16 Machining, ASM Inc., Metals Park, OH, 844, 1989.
Dahn CJ. Explosively nd pyrophoricity of metal powders, Metals Handbook 9th ed., Vol.7 Powder Metallurgy, ASM Int., Metals Park, OH, 194-200, 1989.

Ho WF, Cheng CH, Pan CH, Wu SC, Hsu HC. Structure, mechanical properties and grindability of dental Ti-10Zr-X alloys, Mater Sci Eng C, 29, 36-43, 2009.

Ho WF, Chen WK, Wu SC. Structure, mechanical properties, and grindability of dental $\mathrm{Ti}-\mathrm{Zr}$ alloys, J Mater Sci: Mater Med, 19, 31793186, 2008.

Jung JH. Mechanical properties and corrosion resistance of $\mathrm{Ti}-\mathrm{Zr}-(\mathrm{Nb}, \mathrm{Pd})$ based alloys for biomedical applications, Major in metallugical engineering graduate school, Chosun university, p.46, 2000.

Jung JH, Noh HR. Grindability of cast Ti$\mathrm{X} \% \operatorname{Zr}(\mathrm{X}=10,20,40)$ alloys for dental applications, J KADT, 33(4), 263-270, 2011.

Kikuchi M, Takada Y, Kiyosue S, Yoda M, Woldu M, Cai Z, Okuno O, Okabe T. Grindability of cast Ti-Cu alloys, Dent Mater, 19, 375-381, 2003.

Kikuchi M, Takahashi M, Sato H, Okuno O, Nunn ME, Okabe T. Grindabilty of cast Ti-Hf alloys, J Biomed Mater Res, Part B: Appl Biomater., 77B, 34-38, 2006.

Murray Jl. Binary alloy phase diagrams, in alloy phase diagram, ed by Baker A, ASTM International, Materials Park, OH, 340, 1987.

Nakajima H, Okabe T. Titanium in dentistry: Developmental and research in the U.S.A., Dent Mater J, 15(2), 77-90, 1996.

Okazaki Y, Asao S, Rao S, Tateishi T. Effect of concentration of Zr, Sn, Nb, Ta, Pd, Mo, Co, $\mathrm{Cr}, \mathrm{Si}, \mathrm{Ni}, \mathrm{Fe}$ on the relative growth ratios of bio-cells, J Japan Inst Metals, 60(9), 902, 1996. 
| 정종현 · 신재우

Takeyama H, Murata R. Study on machinability of pure titanium, J Jpn Soc Preci Eng, 28:6, 331, 1996.

Watanabe I, Kiyosue S, Ohkubo C, Aoki T, Okabe T. Machinality of cast commercial titanium alloys, J Biomed Mater Res(Appl Biomater, 63, 760-764, 2002. 